This Section of Epidemiology and Psychiatric Sciences regularly appears in each issue of the Journal to describe relevant studies investigating the relationship between neurobiology and psychosocial psychiatry in major psychoses. The aim of these Editorials is to provide a better understanding of the neural basis of psychopathology and clinical features of these disorders, in order to raise new perspectives in every-day clinical practice.

Paolo Brambilla, Section Editor and Michele Tansella, Editor EPS

\title{
Brain anatomy of autism spectrum disorders I. Focus on corpus callosum
}

\author{
M. Bellani ${ }^{1 *}$, S. Calderoni ${ }^{2}$, F. Muratori ${ }^{2,3}$ and P. Brambilla ${ }^{4,5}$ \\ ${ }^{1}$ Department of Public Health and Community Medicine, Section of Psychiatry and Section of Clinical Psychology, Inter-University Center for \\ Behavioural Neurosciences (ICBN), University of Verona, Verona, Italy \\ ${ }^{2}$ IRCCS Stella Maris Foundation, Pisa, Italy \\ ${ }^{3}$ Department of Child Neurology and Psychiatry, University of Pisa, Pisa, Italy \\ ${ }^{4}$ Department of Experimental Clinical Medicine, Inter-University Center for Behavioural Neurosciences (ICBN), University of Udine, Udine, Italy \\ ${ }^{5}$ Department of Psychiatry and Behavioral Sciences, University of Texas Medical School at Houston, TX, USA
}

This brief review aims to examine the structural magnetic resonance imaging (sMRI) studies on corpus callosum in autism spectrum disorders (ASD) and discuss the clinical and demographic factors involved in the interpretation of results.

Received 7 February 2013; Revised 14 February 2013; Accepted 21 February 2013; First published online 26 March 2013

Key words: autism spectrum disorders (ASD), corpus callosum, magnetic resonance imaging (MRI), volumes.

Autism spectrum disorders (ASD) are a heterogeneous group of neurodevelopmental pathologies whose diagnosis is based on the behavioural symptoms (Muratori et al. 2011) and whose intervention strategies aimed at improving socio-communicative skills as well as daily life abilities (Bellani et al. 2011). The neuroanatomical correlates of ASD are not fully elucidated. However, consistent findings based on structural magnetic resonance imaging (sMRI) data reported widespread cerebral abnormalities that include differences between ASD patients and controls in total brain volume, fronto-parieto-temporal and cerebellar regions. Moreover, a replicated altered corpus callosum (CC) size has been reported in the first SMRI analyses (for a review, see Brambilla et al. 2003). In particular, the altered CC has been considered as an anatomical

* Address for correspondence: Dr. M. Bellani, Department of Public Health and Community Medicine, Section of Psychiatry and Section of Clinical Psychology, University of Verona, Piazzale L.A. Scuro 10, 37134 Verona, Italy.

(Email: marcella.bellani@univr.it) substrate of processing and integration deficits peculiar to ASD, supporting the hypothesis of abnormal cortical connectivity in autism (Just et al. 2007). The CC is the largest commissural white matter (WM) tract in the human brain, and is conventionally divided into anterior CC, which comprises the rostrum, genu, rostral body, anterior mid-body and posterior CC, which includes the posterior mid-body, isthmus and splenium (Witelson, 1989). This primary WM structure connects homologous and heterotopic cortical areas of the two cerebral hemispheres and it is thought to be involved in motor and sensory integration as well as in higher cognitive function, including abstract reasoning, problem solving, ability to generalize, planning, social skills, attention, arousal, language comprehension and expression of syntax and pragmatics, emotion, memory (Paul et al. 2007). Recent investigations have employed a threedimensional volumetric measurement of CC in ASD and frequently reported a reduction in the overall structure (Hardan et al. 2009; McAlonan et al. 2009; Duan et al. 2010; Anderson et al. 2011; Frazier et al. 
Table 1. Studies investigating CC volumetry in patients with ASD compared with typically developing control subjects

\begin{tabular}{|c|c|c|c|c|c|}
\hline Study & Subjects & Age years (SD) & Full-scale IQ & MRI methods & $\begin{array}{l}\text { Significant findings in } \\
\text { ASD relative to controls }\end{array}$ \\
\hline $\begin{array}{l}\text { Herbert et al. } \\
\text { (2004) }\end{array}$ & $\begin{array}{l}13 \mathrm{AD} \\
21 \mathrm{DLD} \\
29 \mathrm{TD}\end{array}$ & $\begin{array}{l}9.0(0.9) \\
8.2(1.6) \\
9.1(1.2)\end{array}$ & $\begin{array}{l}\mathrm{PIQ}>80 \\
\mathrm{PIQ}>80 \\
\text { n.r. }\end{array}$ & $\begin{array}{l}\text { Quantitative volumetric } \\
\text { analysis, } 1.5 \mathrm{~T}\end{array}$ & $\begin{array}{l}\text { No differences in CC } \\
\text { volume }\end{array}$ \\
\hline $\begin{array}{l}\text { Waiter et al. } \\
\text { (2004) }\end{array}$ & $\begin{array}{l}16 \mathrm{ASD} \\
16 \mathrm{TD}\end{array}$ & $\begin{array}{c}15.4(2.24) \\
15.5(1.6)\end{array}$ & $\begin{array}{c}100.4(21.7) \\
99.7(18.3)\end{array}$ & VBM, $1.5 \mathrm{~T}$ & $\begin{array}{c}\text { No differences in CC } \\
\text { volume }\end{array}$ \\
\hline $\begin{array}{l}\text { Waiter et al. } \\
\text { (2005) }\end{array}$ & $\begin{array}{l}15 \mathrm{ASD} \\
16 \mathrm{TD}\end{array}$ & $\begin{array}{l}15.2(2.2) \\
15.5(1.6)\end{array}$ & $\begin{array}{c}100.5(22.4) \\
99.7(18.3)\end{array}$ & VBM, $1.5 \mathrm{~T}$ & $\begin{array}{l}\text { Reduction in CC } \\
\text { volume, particularly in } \\
\text { the posterior regions }\end{array}$ \\
\hline $\begin{array}{l}\text { Vidal et al. } \\
\qquad(2006)\end{array}$ & $\begin{array}{l}24 \mathrm{HFA} \\
26 \mathrm{TD}\end{array}$ & $\begin{array}{l}10.0(3.3) \\
11.0(2.5)\end{array}$ & $\begin{array}{c}95.9(11.5) \\
104.8(11.7)\end{array}$ & $\begin{array}{l}\text { Three-dimensional } \\
\text { surface models, } 3 \mathrm{~T}\end{array}$ & $\begin{array}{l}\text { Reduction in the } \\
\text { splenium and genu of } \\
\text { CC }\end{array}$ \\
\hline $\begin{array}{l}\text { Alexander } \\
\text { et al. (2007) }\end{array}$ & $\begin{array}{l}43 \mathrm{ASD} \\
34 \mathrm{TD}\end{array}$ & $\begin{array}{l}16.2(6.7) \\
16.4(6.0)\end{array}$ & $\begin{array}{l}\text { PIQ } 107.5(13.0) \\
\text { PIQ } 112.8(12.1)\end{array}$ & DTI, $3.0 \mathrm{~T}$ & $\begin{array}{c}\text { Reduction in CC } \\
\text { volume, particularly in } \\
\text { the anterior regions }\end{array}$ \\
\hline $\begin{array}{l}\text { Bonilha et al. } \\
\text { (2008) }\end{array}$ & $\begin{array}{l}12 \mathrm{AD} \\
16 \mathrm{TD}\end{array}$ & $\begin{array}{l}12.4(4) \\
13.2(5)\end{array}$ & $\begin{array}{l}\text { n.r. } \\
\text { n.r. }\end{array}$ & VBM, $2.0 \mathrm{~T}$ & $\begin{array}{c}\text { No differences in CC } \\
\text { volume }\end{array}$ \\
\hline $\begin{array}{l}\text { Ke } e t \text { al. } \\
\quad(2008)\end{array}$ & $\begin{array}{c}17 \text { HFA } \\
15 \text { TD }\end{array}$ & $\begin{array}{l}8.9(2.0) \\
9.7(1.7)\end{array}$ & $\begin{array}{l}108.8(19.1) \\
109.8(19.2)\end{array}$ & VBM, $1.5 \mathrm{~T}$ & $\begin{array}{c}\text { No differences in CC } \\
\text { volume }\end{array}$ \\
\hline $\begin{array}{l}\text { Hardan et al. } \\
\text { (2009) }\end{array}$ & $\begin{array}{l}22 \mathrm{ASD} \\
23 \mathrm{TD}\end{array}$ & $\begin{array}{l}10.7(1.4) \\
10.5(1.4)\end{array}$ & $\begin{array}{c}95.1(20.4) \\
116.2(13.2)\end{array}$ & $\begin{array}{l}\text { ROI manual } \\
\text { tracing, } 1.5 \mathrm{~T}\end{array}$ & $\begin{array}{c}\text { Reduction in CC } \\
\text { volume }\end{array}$ \\
\hline $\begin{array}{l}\text { Keary et al. } \\
\text { (2009) }\end{array}$ & $\begin{array}{l}32 \mathrm{ASD} \\
34 \mathrm{TD}\end{array}$ & $\begin{array}{c}19.8(10.2) \\
18.6(9.1)\end{array}$ & $\begin{array}{l}102.9(13.6) \\
104.0(10.5)\end{array}$ & $\begin{array}{l}\text { ROI manual } \\
\text { tracing, } 1.5 \mathrm{~T}\end{array}$ & $\begin{array}{l}\text { Reduction in CC } \\
\text { volume, particularly in } \\
\text { the anterior regions }\end{array}$ \\
\hline $\begin{array}{l}\text { McAlonan } \\
\text { et al. (2009) }\end{array}$ & $\begin{array}{l}18 \text { HFA } \\
18 \text { ASP } \\
54 \text { TD }\end{array}$ & $\begin{array}{l}11.6(2.9) \\
11.2(2.5) \\
10.7(2.7)\end{array}$ & $\begin{array}{l}\text { VIQ } 114.8(19.1) \\
\text { VIQ } 109.8(16.2) \\
\text { VIQ } 117.1(18.1)\end{array}$ & VBM, $1.5 \mathrm{~T}$ & $\begin{array}{l}\text { Reduction in the genu } \\
\text { of CC in HFA and ASP }\end{array}$ \\
\hline $\begin{array}{l}\text { Duan et al. } \\
\qquad(2010)\end{array}$ & $\begin{array}{c}30 \mathrm{ASD} \\
28 \mathrm{TD}\end{array}$ & $\begin{array}{l}\text { Age range: } 3-30 \\
\text { Age range: } 3-30\end{array}$ & $\begin{array}{l}\geq 40 \\
\text { n.r. }\end{array}$ & $\begin{array}{l}\text { ROI manual } \\
\text { tracing, } 1.5 \mathrm{~T}\end{array}$ & $\begin{array}{c}\text { Reduction in CC } \\
\text { volume and in all its } \\
\text { sub-regions }\end{array}$ \\
\hline $\begin{array}{l}\text { Ecker et al. } \\
\quad(2010)\end{array}$ & $\begin{array}{l}22 \mathrm{ASD} \\
22 \mathrm{TD}\end{array}$ & $\begin{array}{l}27(7) \\
28(7)\end{array}$ & $\begin{array}{c}104(15) \\
111(10.0)\end{array}$ & VBM, $3.0 \mathrm{~T}$ & $\begin{array}{c}\text { No differences in CC } \\
\text { volume }\end{array}$ \\
\hline $\begin{array}{l}\text { Toal et al. } \\
\text { (2010) }\end{array}$ & $\begin{array}{l}26 \mathrm{AD} \\
39 \mathrm{ASP} \\
33 \mathrm{TD}\end{array}$ & $\begin{array}{c}30(8) \\
32(12) \\
32(9)\end{array}$ & $\begin{array}{c}84(23) \\
106(15) \\
105(12)\end{array}$ & VBM, $1.5 \mathrm{~T}$ & $\begin{array}{l}\text { No differences in CC } \\
\text { volume }\end{array}$ \\
\hline $\begin{array}{l}\text { Anderson } \\
\text { et al. (2011) }\end{array}$ & $\begin{array}{l}53 \text { HFA } \\
39 \text { TD }\end{array}$ & $\begin{array}{l}22.4(7.2) \\
21.1(6.5)\end{array}$ & $\begin{array}{l}\text { PIQ } 101.3(16.5) \\
\text { PIQ } 114.2(13.9)\end{array}$ & $\begin{array}{c}\text { Automated volumetric } \\
\text { segmentation, } 3.0 \mathrm{~T}\end{array}$ & $\begin{array}{c}\text { Reduction in CC } \\
\text { volume }\end{array}$ \\
\hline $\begin{array}{l}\text { Cheng et al. } \\
\text { (2011) }\end{array}$ & $\begin{array}{c}25 \mathrm{ASD} \\
25 \mathrm{TD}\end{array}$ & $\begin{array}{l}13.7(2.5) \\
13.5(2.1)\end{array}$ & $\begin{array}{c}101.6(18.9) \\
109.0(9.5)\end{array}$ & VBM, $1.5 \mathrm{~T}$ & $\begin{array}{c}\text { No differences in CC } \\
\text { volume }\end{array}$ \\
\hline $\begin{array}{l}\text { Hong et al. } \\
\qquad(2011)\end{array}$ & $\begin{array}{l}18 \text { HFA } \\
16 \text { TD }\end{array}$ & $\begin{array}{l}8.7(2.2) \\
9.8(1.9)\end{array}$ & $\begin{array}{l}105.2(21.1) \\
106.1(20.1)\end{array}$ & $\begin{array}{l}\text { ROI manual } \\
\text { tracing, } 1.5 \mathrm{~T}\end{array}$ & $\begin{array}{l}\text { No differences in } \\
\text { overall CC volume and } \\
\text { its sub-regions }\end{array}$ \\
\hline $\begin{array}{l}\text { Mengotti } \\
\text { et al. (2011) }\end{array}$ & $\begin{array}{l}20 \mathrm{AD} \\
22 \mathrm{TD}\end{array}$ & $\begin{array}{l}7.0(2.7) \\
7.7(2.0)\end{array}$ & $\begin{array}{c}\text { Evaluated, but } \\
\text { n.r. }\end{array}$ & DTI and VBM, $1.5 \mathrm{~T}$ & $\begin{array}{c}\text { No differences in CC } \\
\text { volume }\end{array}$ \\
\hline $\begin{array}{l}\text { Riva et al. } \\
\text { (2011) }\end{array}$ & $\begin{array}{l}21 \text { LFASD } \\
21 \mathrm{TD}\end{array}$ & $\begin{array}{l}6.6(2.5) \\
6.10(2.1)\end{array}$ & $\begin{array}{c}52.5(9.8) \\
\text { normal IQ }\end{array}$ & VBM, $1.5 \mathrm{~T}$ & $\begin{array}{c}\text { No differences in CC } \\
\text { volume }\end{array}$ \\
\hline $\begin{array}{l}\text { Thomas et al. } \\
\text { (2011) }\end{array}$ & $\begin{array}{l}12 \mathrm{HFA} \\
18 \mathrm{TD}\end{array}$ & $\begin{array}{l}28.5(9.7) \\
22.4(4.1)\end{array}$ & $\begin{array}{c}106.9(10.5) \\
111.6(9.9)\end{array}$ & DTI, $3.0 \mathrm{~T}$ & $\begin{array}{l}\text { Reduction in the body } \\
\text { of } C C\end{array}$ \\
\hline $\begin{array}{l}\text { Calderoni } \\
\text { et al. (2012) }\end{array}$ & $\begin{array}{c}38 \text { ASD (19 with } \\
\text { DD, } 19 \text { no DD) } \\
38 \text { controls } \\
\text { (19 with DD, } \\
19 \text { TD) }\end{array}$ & $\begin{array}{l}4.4(1.5) \\
4.4(1.6)\end{array}$ & $\begin{array}{l}72(20) \\
73(25)\end{array}$ & VBM, $1.5 \mathrm{~T}$ & $\begin{array}{c}\text { No differences in CC } \\
\text { volume }\end{array}$ \\
\hline
\end{tabular}


Table 1. Continued

\begin{tabular}{|c|c|c|c|c|c|}
\hline Study & Subjects & Age years (SD) & Full-scale IQ & MRI methods & $\begin{array}{l}\text { Significant findings in } \\
\text { ASD relative to controls }\end{array}$ \\
\hline $\begin{array}{l}\text { Frazier et al. } \\
\qquad(2012)\end{array}$ & $\begin{array}{c}23 \mathrm{ASD} \\
23 \mathrm{TD}\end{array}$ & $\begin{array}{c}\text { 10.6; range: } \\
\text { 8-12 } \\
\text { 10.5; range: } 7-13\end{array}$ & $\begin{array}{c}94.6(20.0) \\
116.2(13.2)\end{array}$ & $\begin{array}{l}\text { ROI manual } \\
\text { tracing, } 1.5 \mathrm{~T}\end{array}$ & $\begin{array}{l}\text { Reduction in CC } \\
\text { volume }\end{array}$ \\
\hline $\begin{array}{l}\text { Frazier et al. } \\
\qquad(2012)^{*}\end{array}$ & $\begin{array}{l}18 \mathrm{ASD} \\
19 \mathrm{TD}\end{array}$ & $\begin{array}{c}\text { 13.1; range: } \\
\text { 9-15 } \\
\text { 12.4; range: 9-16 }\end{array}$ & $\begin{array}{c}94.6(20.0) \\
116.2(13.2)\end{array}$ & $\begin{array}{l}\text { ROI manual } \\
\text { tracing, } 1.5 \mathrm{~T}\end{array}$ & $\begin{array}{l}\text { Reduction in CC } \\
\text { volume, with the } \\
\text { exception of rostral } \\
\text { body }\end{array}$ \\
\hline
\end{tabular}

$\mathrm{AD}$, autistic disorder; ASD, autism spectrum disorders; ASP, Asperger's syndrome; DD, developmental delay; DLD, developmental language disorder; CC, corpus callosum; DTI, diffusion tensor imaging; HFA, high-functioning autism; LFA, lowfunctioning autism; no DD, without developmental delay; n.r., not reported; PIQ, performance IQ; ROI, region of interest; $\mathrm{TD}$, typically developing control subjects; VBM, voxel-based morphometry.

*Follow-up study.

2012), or in one or more components of this axonal pathway, including the anterior (Alexander et al. 2007; Keary et al. 2009; Thomas et al. 2011), the posterior sub-regions (Waiter et al. 2005) or some of the anterior and posterior regions contemporaneously (Vidal et al. 2006). The reductions in the CC volume is present over a wide age-range, since it is reported in ASD studies involving children (Vidal et al. 2006; Hardan et al. 2009; McAlonan et al. 2009; Frazier et al. 2012), adolescents (Waiter et al. 2004, 2005; Alexander et al. 2007) and adults (Keary et al. 2009; Ecker et al. 2010; Anderson et al. 2011; Thomas et al. 2011). On the other hand, the sparse literature on CC volume in low-functioning ASD (Riva et al. 2011) prevents us from drawing inferences about the influence of IQ on $\mathrm{CC}$ volume and calls for further investigation. Only a relatively few studies did not reveal significant CC volume differences between ASD patients and typically developing controls; in particular, this finding has been reported more often in voxel-based morphometry (Waiter et al. 2004; Bonilha et al. 2008; Ke et al. 2008; Ecker et al. 2010; Toal et al. 2010; Cheng et al. 2011; Mengotti et al. 2011; Calderoni et al. 2012) than in region of interest-based (Hong et al. 2011) analyses. Notably, to our knowledge, there have been no published studies reporting volumetric increase of CC (Table 1). Anyway, till date, few papers have examined the relationship between demographic/clinical data and CC volume in ASD patients. Interestingly, positive correlations of age with total CC volume were observed in ASD subjects when a longitudinal design was performed (Frazier et al. 2012), whereas a crosssectional approach failed to detect such relationship (Alexander et al. 2007). In addition, volume reduction in the CC has been found to correlate with core ASD features such social deficits, repetitive behaviours and sensory abnormalities (Frazier et al. 2012), as well as executive function and complex motor tasks deficits (Keary et al. 2009).

In sum, although there is more evidence to support the notion that the $\mathrm{CC}$ volume, especially its anterior sectors, is decreased in ASD, there are some suggestions that no differences relative to controls occurs. Specifically, the CC volume reduction may be related to altered patterns of connectivity between brain areas, and in turn it might be responsible for some of the cardinal behavioural impairments of ASD. However, a number of crucial questions remain unanswered: volumetric alterations of the CC are specific to ASD or are a more general marker of abnormal brain development shared with other neuropsychiatric disorders? What is the relationship between alterations of the CC volume and demographic and clinical variables such as age, gender, handedness, intellective functioning, severity of symptoms, psychiatric comorbidity, psychotropic medications? What is the contribution of different CC subdivisions to overall CC volume alterations? Do the $\mathrm{CC}$ volume alterations persist into adulthood? What are the underlying neuropathological changes (e.g. reduction in number and/ or size of axons, impaired myelination, excessive synaptic pruning) responsible for decreased CC volume? Future dedicated studies should aim to address these issues more specifically.

\section{Acknowledgements}

None.

\section{Financial Support}

S. C. was partly supported by the Italian Ministry of Health and by Tuscany Region with the grant 
'GR-2010-2317873'. F. M. and S. C. were partly supported by the European Union (The MICHELANGELO Project). The other authors received no specific grant from any funding agency, commercial or not-for-profit sectors.

\section{Conflict of Interest}

None.

\section{Ethical Standards}

The authors declare that no human or animal experimentation was conducted for this work.

\section{References}

Alexander AL, Lee JE, Lazar M, Boudos R, DuBray MB, Oakes TR, Miller JN, Lu J, Jeong EK, McMahon WM, Bigler ED, Lainhart JE (2007). Diffusion tensor imaging of the corpus callosum in autism. Neuroimage 34, 61-73.

Anderson JS, Druzgal TJ, Froehlich A, DuBray MB, Lange N, Alexander AL, Abildskov T, Nielsen JA, Cariello AN, Cooperrider JR, Bigler ED, Lainhart JE (2011). Decreased interhemispheric functional connectivity in autism. Cerebral Cortex 21, 1134-1146.

Bellani M, Fornasari L, Chittaro L, Brambilla P (2011). Virtual reality in autism: state of the art. Epidemiology and Psychiatric Sciences 20, 235-238.

Bonilha L, Cendes F, Rorden C, Eckert M, Dalgalarrondo P, Li LM, Steiner CE (2008). Gray and white matter imbalance-typical structural abnormality underlying classic autism? Brain and Development 30, 396-401.

Brambilla P, Hardan A, di Nemi SU, Perez J, Soares JC, Barale F (2003). Brain anatomy and development in autism: review of structural MRI studies. Brain Research Bulletin 61, 557-569.

Calderoni S, Retico A, Biagi L, Tancredi R, Muratori F, Tosetti M (2012). Female children with autism spectrum disorder: an insight from mass-univariate and pattern classification analyses. Neuroimage 59, 1013-1022.

Cheng Y, Chou KH, Fan YT, Lin CP (2011). ANS: aberrant neurodevelopment of the social cognition network in adolescents with autism spectrum disorders. PLOS ONE 6, e18905.

Duan Y, He Q, Yin X, Gu X, Karsch K, Miles J (2010). Detecting corpus callosum abnormalities in autism subtype using planar conformal mapping. International Journal for Numerical Methods in Biomedical Engineering 26, 164-175.

Ecker C, Rocha-Rego V, Johnston P, Mourao-Miranda J, Marquand A, Daly EM, Brammer MJ, Murphy C, Murphy DG; MRC AIMS Consortium (2010). Investigating the predictive value of whole-brain structural MR scans in autism: a pattern classification approach. NeuroImage 49, 44-56.

Frazier TW, Keshavan MS, Minshew NJ, Hardan AY (2012). A two-year longitudinal MRI study of the corpus callosum in autism. Journal of Autism and Developmental Disorders 42, 2312-2322.

Hardan AY, Pabalan M, Gupta N, Bansal R, Melhem NM, Fedorov S (2009). Corpus callosum volume in children with autism. Psychiatry Research: Neuroimaging 174, 57-61.

Herbert MR, Ziegler DA, Makris N, Filipek PA, Kemper TL, Normandin JJ, Sanders HA, Kennedy DN, Caviness Jr. VS (2004). Localization of white matter volume increase in autism and developmental language disorder. Annals of Neurology 55, 530-540.

Hong S, Ke X, Tang T, Hang Y, Chu K, Huang H, Ruan Z, Lu Z, Tao G, Liu Y (2011). Detecting abnormalities of corpus callosum connectivity in autism using magnetic resonance imaging and diffusion tensor tractography. Psychiatry Research: Neuroimaging 194, 333-339.

Just MA, Cherkassky VL, Keller TA, Kana RK, Minshew NJ (2007). Functional and anatomical cortical underconnectivity in autism: evidence from an fMRI study of an executive function task and corpus callosum morphometry. Cerebral Cortex 17, 951-961.

Ke X, Hong S, Tang T, Zou B, Li H, Hang Y, Zhou Z, Ruan Z, Lu Z, Tao G, Liu Y (2008). Voxel-based morphometry study on brain structure in children with high-functioning autism. Neuroreport 19, 921-925.

Keary CJ, Minshew NJ, Bansal R, Goradia D, Fedorov S, Keshavan MS, Hardan AY (2009). Corpus callosum volume and neurocognition in autism. Journal of Autism and Developmental Disorders 39, 834-841.

McAlonan GM, Cheung C, Cheung V, Wong N, Suckling J, Chua SE (2009). Differential effects on white-matter systems in high-functioning autism and Asperger's syndrome. Psychological Medicine 39, 1885-1893.

Mengotti P, D’Agostini S, Terlevic R, De Colle C, Biasizzo E, Londero D, Ferro A, Rambaldelli G, Balestrieri M, Zanini S, Fabbro F, Molteni M, Brambilla P (2011). Altered white matter integrity and development in children with autism: a combined voxel-based morphometry and diffusion imaging study. Brain Research Bulletin 84, 189-195.

Muratori F, Narzisi A, Tancredi R, Cosenza A, Calugi S, Saviozzi I, Santocchi E, Calderoni S (2011). The CBCL 1.5-5 and the identification of preschoolers with autism in Italy. Epidemiology and Psychiatric Sciences 20, 329-338.

Paul LK, Brown WS, Adolphs R, Tyszka JM, Richards LJ, Mukherjee P, Sherr EH (2007). Agenesis of the corpus callosum: genetic, developmental and functional aspects of connectivity. Nature Reviews Neuroscience 8, 287-299.

Riva D, Bulgheroni S, Aquino D, Di Salle F, Savoiardo M, Erbetta A (2011). Basal forebrain involvement in low-functioning autistic children: a voxel-based morphometry study. AJNR. American Journal of Neuroradiology 32, 1430-1435.

Thomas C, Humphreys K, Jung KJ, Minshew N, Behrmann M (2011). The anatomy of the callosal and visual-association pathways in high-functioning autism: a DTI tractography study. Cortex 47, 863-873.

Toal F, Daly EM, Page L, Deeley Q, Hallahan B, Bloemen O, Cutter WJ, Brammer MJ, Curran S, Robertson D, Murphy C, Murphy KC, Murphy DG (2010). Clinical and anatomical heterogeneity in autistic spectrum disorder: a structural MRI study. Psychological Medicine 40, 1171-1181.

Vidal CN, Nicolson R, DeVito TJ, Hayashi KM, Geaga JA, Drost DJ, Williamson PC, Rajakumar N, Sui Y, Dutton RA, 
Toga AW, Thompson PM (2006). Mapping corpus callosum deficits in autism: an index of aberrant cortical connectivity. Biological Psychiatry 60, 218-225.

Waiter GD, Williams JH, Murray AD, Gilchrist A, Perrett DI, Whiten A (2004). A voxel-based investigation of brain structure in male adolescents with autistic spectrum disorder. NeuroImage 22, 619-625.
Waiter GD, Williams JH, Murray AD, Gilchrist A, Perrett DI, Whiten A (2005). Structural white matter deficits in high-functioning individuals with autistic spectrum disorder: a voxel-based investigation. NeuroImage 24, 455-461.

Witelson SF (1989). Hand and sex differences in the isthmus and genu of the human corpus callosum: a postmortem morphological study. Brain 112, 799-835. 